\title{
Formation and mechanical properties of $\mathrm{Cu}-\mathrm{Hf}-\mathrm{Ti}$ bulk glassy alloys
}

\author{
Akihisa Inoue \\ Institute for Materials Research, Tohoku University, Sendai 980-8577, Japan and Inoue Superliquid \\ Glass Project, Exploratory Research for Advanced Technology, Japan Science and Technology \\ Corporation, Sendai 982-0807, Japan \\ Wei Zhang \\ Inoue Superliquid Glass Project, Exploratory Research for Advanced Technology, Japan Science and \\ Technology Corporation, Sendai 982-0807, Japan \\ Tao Zhang \\ Institute for Materials Research, Tohoku University, Sendai 980-8577, Japan
}

Kei Kurosaka

Graduate School, Tohoku University, Sendai 980-8577, Japan

(Received 15 May 2001; accepted 19 July 2001)

\begin{abstract}
High-strength $\mathrm{Cu}$-based bulk glassy alloys were formed in the $\mathrm{Cu}-\mathrm{Hf}-\mathrm{Ti}$ system by the copper mold casting and melt clamp forging methods. The maximum diameter is $4 \mathrm{~mm}$ for the $\mathrm{Cu}_{60} \mathrm{Hf}_{25} \mathrm{Ti}_{15}$ alloy. The substitution of $\mathrm{Hf}$ in the $\mathrm{Cu}_{60} \mathrm{Hf}_{40}$ alloy by $\mathrm{Ti}$ causes an increase in the glass-forming ability (GFA). As the Ti content increases, the glass transition temperature $\left(T_{\mathrm{g}}\right)$ decreases, while the crystallization temperature $\left(T_{\mathrm{x}}\right)$ shows a maximum at $5 \% \mathrm{Ti}$ and then decreases, resulting in a maximum supercooled liquid region $\Delta T_{\mathrm{x}}\left(=T_{\mathrm{x}}-T_{\mathrm{g}}\right)$ of $78 \mathrm{~K}$ at $5 \%$ Ti. The liquidus temperature $\left(T_{1}\right)$ has a minimum of $1172 \mathrm{~K}$ around $20 \% \mathrm{Ti}$, and hence, a maximum $T_{\mathrm{g}} / T_{1}$ of 0.62 is obtained at $20 \%$ Ti. The high GFA was obtained at the compositions with high $T_{\mathrm{g}} / T_{1}$. The bulk glassy alloy exhibits tensile fracture strength of $2130 \mathrm{MPa}$, compressive fracture strength of $2160 \mathrm{MPa}$, and compressive plastic elongation of 0.8 to $1.6 \%$. The new $\mathrm{Cu}$-based bulk glassy alloys with high $T_{\mathrm{g}} / T_{1}$ above 0.60 , high fracture strength above $2100 \mathrm{MPa}$, and distinct plastic elongation are encouraging for future development as a new type of bulk glassy alloy that can be used for structural materials.
\end{abstract}

\section{INTRODUCTION}

Since the findings of glassy alloys with a large supercooled liquid region before crystallization in Ln-Al$\mathrm{TM}^{1}$ and $\mathrm{Mg}-\mathrm{Ln}-\mathrm{TM}^{2}(\mathrm{Ln}=$ lanthanide metals) systems, followed by the formations of $\mathrm{Ln}^{-}{ }^{3}$ and $\mathrm{Mg}$ based ${ }^{4}$ bulk glassy alloys by use of the high stability of supercooled liquid against crystallization, a number of bulk glassy alloys have been developed in multicomponent systems such as $\mathrm{Zr},{ }^{5,6} \mathrm{Ti},{ }^{7} \mathrm{Fe},{ }^{8} \mathrm{Pd}-\mathrm{Cu},{ }^{9} \mathrm{Ni},{ }^{10}$ and $\mathrm{Co}^{11}$ bases. Thus, the bulk glassy alloys have been extended to engineering important alloy systems including Fe-, Co-, Ni-, Ti-, and Mg-based alloys. However, there have been no data on the formation of bulk glassy alloys in $\mathrm{Al}$ - and $\mathrm{Cu}$-based alloy systems containing more than 50 at. $\% \mathrm{Al}$ or $\mathrm{Cu}$, though their formations are expected to cause significant extension of application fields of bulk glassy alloys. It is well known that amorphous alloys in a thin ribbon form are formed in a number of $\mathrm{Al}^{-12,13}$ and $\mathrm{Cu}$-based ${ }^{14}$ systems by the melt-spinning technique. The previous data have also reported that the choice of
$\mathrm{Al}-\mathrm{Y}-\mathrm{Co}-\mathrm{Ni}{ }^{15}$ and $\mathrm{Cu}-\mathrm{Ti}-\mathrm{Zr}^{16}$ systems leads to the formation of amorphous alloys with thickness of about 0.8 and $1 \mathrm{~mm}$, respectively. Recently, intensive developments of $\mathrm{Cu}$-based bulk glassy alloys were made by the increase of $\mathrm{Cu}$ content and the decrease in $\mathrm{Al}$ content in the $\mathrm{Zr}-\mathrm{Al}-\mathrm{Ni}-\mathrm{Cu}^{5}$ and $\mathrm{Zr}-\mathrm{Ti}-\mathrm{Al}-\mathrm{Ni}-\mathrm{Cu}^{17}$ base systems and some bulk glassy alloys containing $\mathrm{Cu}$ contents up to 40 at.\% $\mathrm{Cu}$ have been obtained in $\mathrm{Cu}-\mathrm{Ti}-\mathrm{Zr}-\mathrm{Ni},{ }^{18} \mathrm{Cu}-$ $\mathrm{Ti}-\mathrm{Ni}-\mathrm{Si}-\mathrm{B},{ }^{19}$ and $\mathrm{Cu}-\mathrm{Ti}-\mathrm{Zr}-\mathrm{Ni}-\mathrm{Sn}^{20}$ systems. Very recently, we have reported that $\mathrm{Cu}$-based bulk glassy alloys with a thickness of $4 \mathrm{~mm}$ are formed in the $\mathrm{Cu}-\mathrm{Zr}-\mathrm{Ti}$ ternary system and the bulk glassy alloys exhibit good mechanical properties. ${ }^{21}$ As is the case for the developmental history for a number of bulk glassy alloys developed to date, ${ }^{22-24}$ the first success of forming bulk glassy alloys in the $\mathrm{Cu}$-based ternary system defined by $\mathrm{Cu}$ contents more than 50 at.\% allows us to expect the subsequent synthesis of bulk glassy alloys in different $\mathrm{Cu}$ based systems. Considering the similarities of atomic radius and atomic electronic negativity between $\mathrm{Zr}$ and 
Hf elements belonging to the same group number in the periodic table, ${ }^{25}$ similar bulk glassy alloys are also expected to be formed in the $\mathrm{Cu}-\mathrm{Hf}-\mathrm{Ti}$ system. This paper presents the composition range in which a glassy phase is formed in the $\mathrm{Cu}-\mathrm{Hf}-\mathrm{Ti}$ system by copper mold casting and the compositional dependence of thermal stability and mechanical properties of the bulk glassy alloys. The reason for the high glass-forming ability in the ternary system is also discussed.

\section{EXPERIMENTAL PROCEDURE}

Ternary $\mathrm{Cu}-\mathrm{Hf}-\mathrm{Ti}$ alloys were prepared by arc melting the mixtures of pure $\mathrm{Cu}, \mathrm{Hf}$, and $\mathrm{Ti}$ metals in an argon atmosphere. Ribbon samples with a cross section of $0.02 \times 1.2 \mathrm{~mm}^{2}$ were prepared by melt spinning. Bulk alloys in a cylindrical form with a length of $60 \mathrm{~mm}$ and diameters up to $5 \mathrm{~mm}$ were prepared by copper mold casting. In addition, bulk alloys in a sheet form with a dimension of $50 \times 100 \times 2 \mathrm{~mm}^{3}$ were also prepared by the melt clamp forging technique. ${ }^{26,27}$ Glassy structure was identified by x-ray diffraction (XRD), transmission electron microscopy, and optical microscopy. Thermal stability associated with glass transition temperature $\left(T_{\mathrm{g}}\right)$ and crystallization temperature $\left(T_{\mathrm{x}}\right)$ was examined by differential scanning calorimetry (DSC) at a heating rate of $0.67 \mathrm{~K} / \mathrm{s}$. The melting temperature was determined by differential thermal analysis (DTA) at a heating rate of $0.17 \mathrm{~K} / \mathrm{s}$. Mechanical properties were measured with an Instron-type testing machine. The gauge dimensions were $1 \mathrm{~mm}$ in thickness, $2 \mathrm{~mm}$ in width, and $10 \mathrm{~mm}$ in length for tensile tests and $2 \mathrm{~mm}$ in diameter and $4 \mathrm{~mm}$ in height for compressive tests. Fracture surface was examined by scanning electron microscopy. Hardness was measured with a Vickers hardness indenter under a load of $1 \mathrm{~kg}$.

\section{RESULTS}

\section{A. Thermal stability of supercooled liquid}

It has previously been reported that a glassy phase in the $\mathrm{Cu}-\mathrm{Hf}$ binary system is formed in a wide composition range of 30 to 70 at.\% $\mathrm{Hf}^{28}$ Figure 1 shows DSC curves of the melt-spun $\mathrm{Cu}_{100-x} \mathrm{Hf}_{x}(x=30$ to 70 at.\%) glassy alloys. Although no glass transition is observed for the $30 \% \mathrm{Hf}$ and $70 \% \mathrm{Hf}$ alloys, the alloys containing $40 \%$ to $60 \% \mathrm{Hf}$ exhibit the distinct glass transition, followed by a large supercooled liquid region before crystallization. The $T_{\mathrm{g}}$ and $T_{\mathrm{x}}$ decrease with increasing $\mathrm{Hf}$ content from $40 \%$ to $60 \%$, despite that the liquidus temperature of $\mathrm{Hf}$ metal is much higher than that of $\mathrm{Cu}$ metal. It is also seen that the supercooled liquid region defined by the temperature interval between $T_{\mathrm{g}}$ and $T_{\mathrm{x}}$, $\Delta T_{\mathrm{x}}\left(=T_{\mathrm{x}}-T_{\mathrm{g}}\right)$, shows a maximum value of $59 \mathrm{~K}$ at $50 \% \mathrm{Hf}$ and decreases with a deviation from the $\mathrm{Hf}$

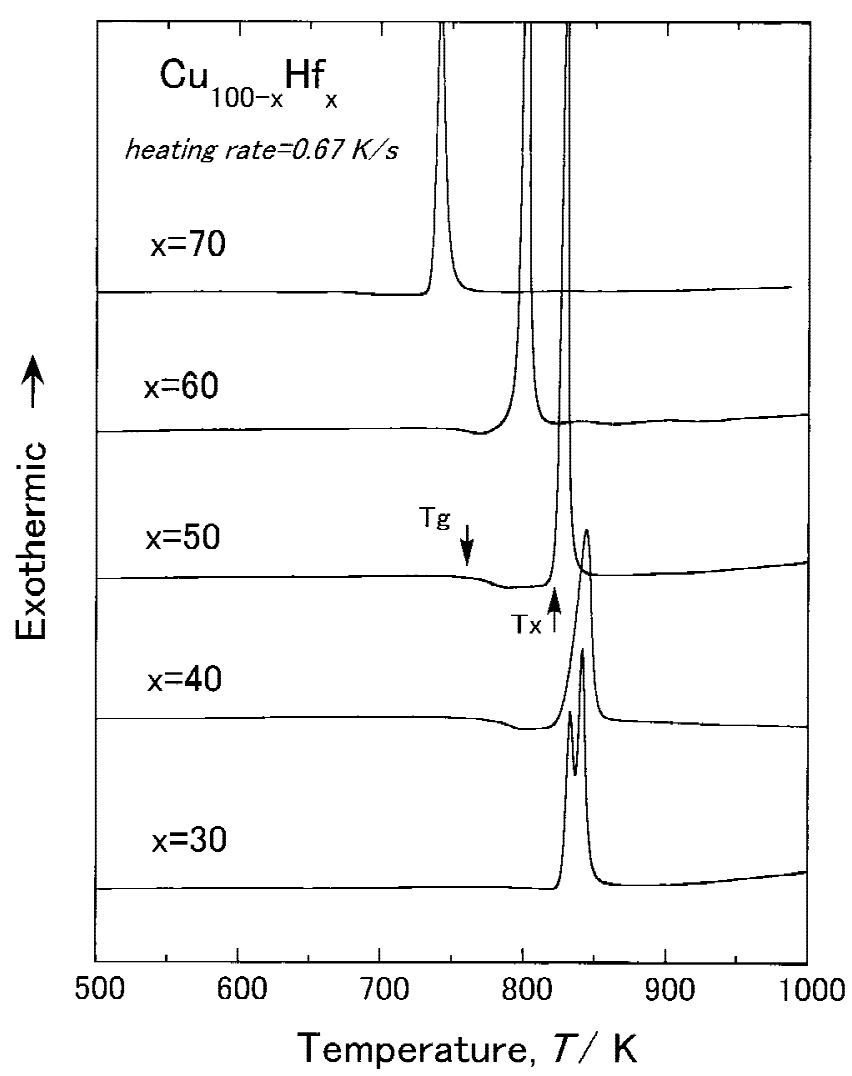

FIG. 1. DSC curves of melt-spun $\mathrm{Cu}_{100-x} \mathrm{Hf}_{x}(x=30$ to 70 at.\%) glassy alloys.

composition. The decrease in $\Delta T_{\mathrm{x}}$ is more distinct in the high $\mathrm{Hf}$ concentration range. The crystallization of the $\mathrm{Cu}-\mathrm{Hf}$ alloys with a supercooled liquid region appears to occur through a single exothermic peak. The single exothermic peak of the $50 \% \mathrm{Hf}$ alloy with the largest supercooled liquid has been confirmed to be due to the precipitation of the $\mathrm{Cu}_{3} \mathrm{Hf}_{\mathrm{z}}$ and $\mathrm{Cu}-\mathrm{Hf}_{\mathrm{z}}$ phases.

Subsequently, we examined the effect of $\mathrm{Ti}$ addition on the glass transition and the thermal stability of supercooled liquid region in the alloy series of $\mathrm{Cu}_{60} \mathrm{Hf}_{40-x} \mathrm{Ti}_{x}$. Figure 2 shows DSC curves of the melt-spun $\mathrm{Cu}_{60} \mathrm{Hf}_{40-x} \mathrm{Ti}_{x}(x=0$ to 40 at.\%) glassy alloys. In comparison with the $\mathrm{Cu}_{60} \mathrm{Hf}_{40}$ binary glassy alloy, the addition of $5 \%$ Ti leads to a significant increase in $\Delta T_{\mathrm{x}}$ to $78 \mathrm{~K}$ through a decrease in $T_{\mathrm{g}}$ and an increase in $T_{\mathrm{x}}$ in the maintenance of the single-stage crystallization mode. However, with further increasing $\mathrm{Ti}$ content, the $\Delta T_{\mathrm{x}}$ decreases due to the more significant decrease in $T_{\mathrm{x}}$ as compared with the decrease in $T_{\mathrm{g}}$, accompanying the change in the crystallization mode from the single stage to multiple stages. The glass transition phenomenon disappears at $40 \%$ Ti. Figure 3 shows the changes in $T_{\mathrm{g}}, T_{\mathrm{x}}$, and $\Delta T_{\mathrm{x}}$ as a function of Ti content for the melt-spun $\mathrm{Cu}_{60} \mathrm{Hf}_{40-x} \mathrm{Ti}_{x}$ glassy alloys. One can confirm a monotonous decrease in $T_{\mathrm{g}}$ from 772 to $703 \mathrm{~K}$ over the whole Ti content, while $T_{\mathrm{x}}$ shows a maximum of $832 \mathrm{~K}$ at 


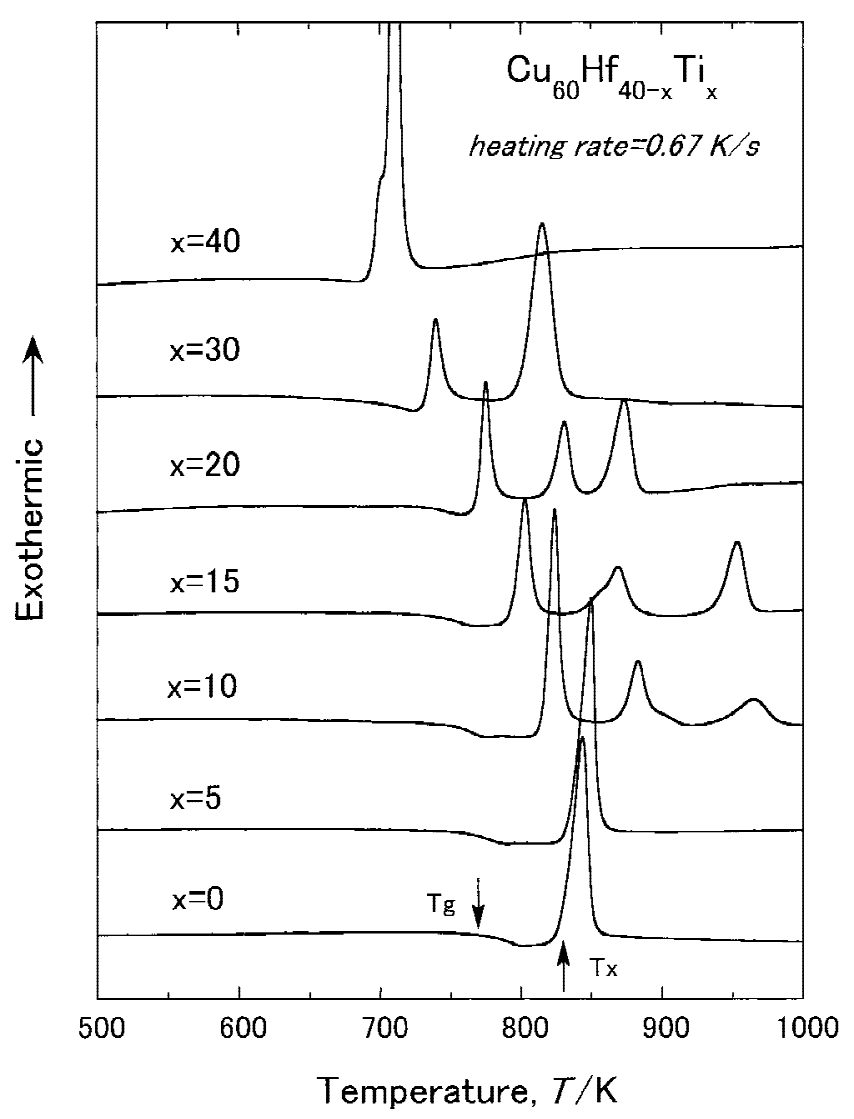

FIG. 2. DSC curves of melt-spun $\mathrm{Cu}_{60} \mathrm{Hf}_{40-x} \mathrm{Ti}_{x}(x=0$ to 40 at. $\%$ ) glassy alloys.

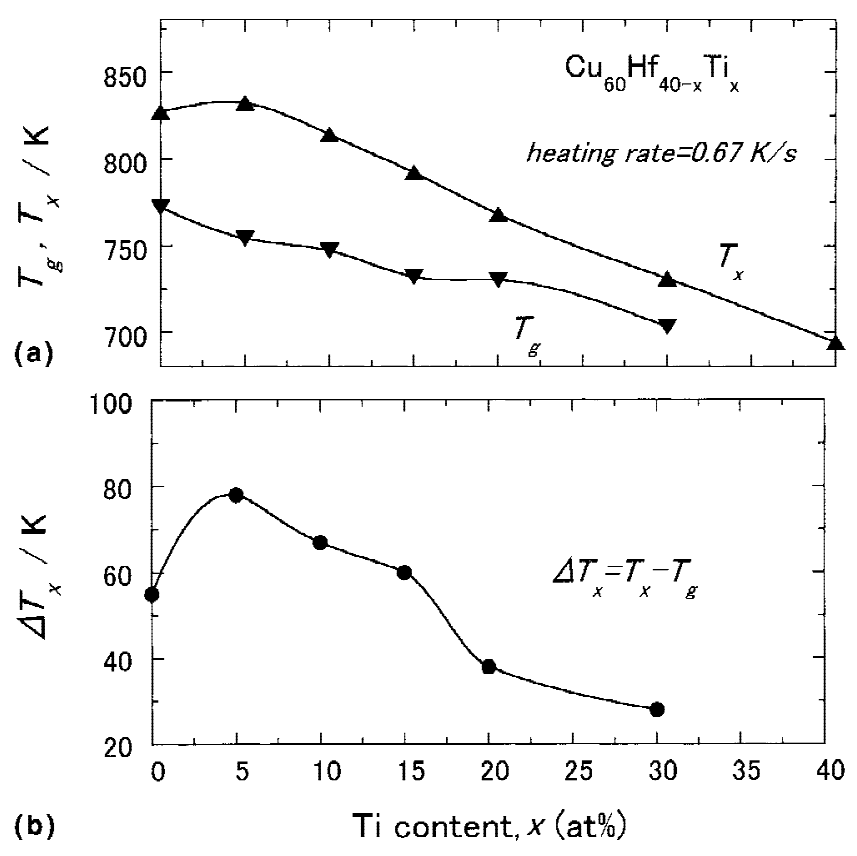

FIG. 3. Glass transition temperature $\left(T_{\mathrm{g}}\right)$, crystallization temperature $\left(T_{\mathrm{x}}\right)$, and supercooled liquid region $\left(\Delta T_{\mathrm{x}}=T_{\mathrm{x}}-T_{\mathrm{g}}\right)$ as a function of $\mathrm{Ti}$ content for melt-spun $\mathrm{Cu}_{60} \mathrm{Hf}_{40-x} \mathrm{Ti}_{x}$ glassy alloys.
$5 \% \mathrm{Ti}$ and then decreases monotonously to $694 \mathrm{~K}$ at $40 \%$ Ti. As a result, $\Delta T_{\mathrm{x}}$ shows a maximum of $78 \mathrm{~K}$ at $5 \% \mathrm{Ti}$, followed by a gradual decrease to $60 \mathrm{~K}$ at $15 \% \mathrm{Ti}$ and then a significant decrease to $28 \mathrm{~K}$ at $30 \% \mathrm{Ti}$.

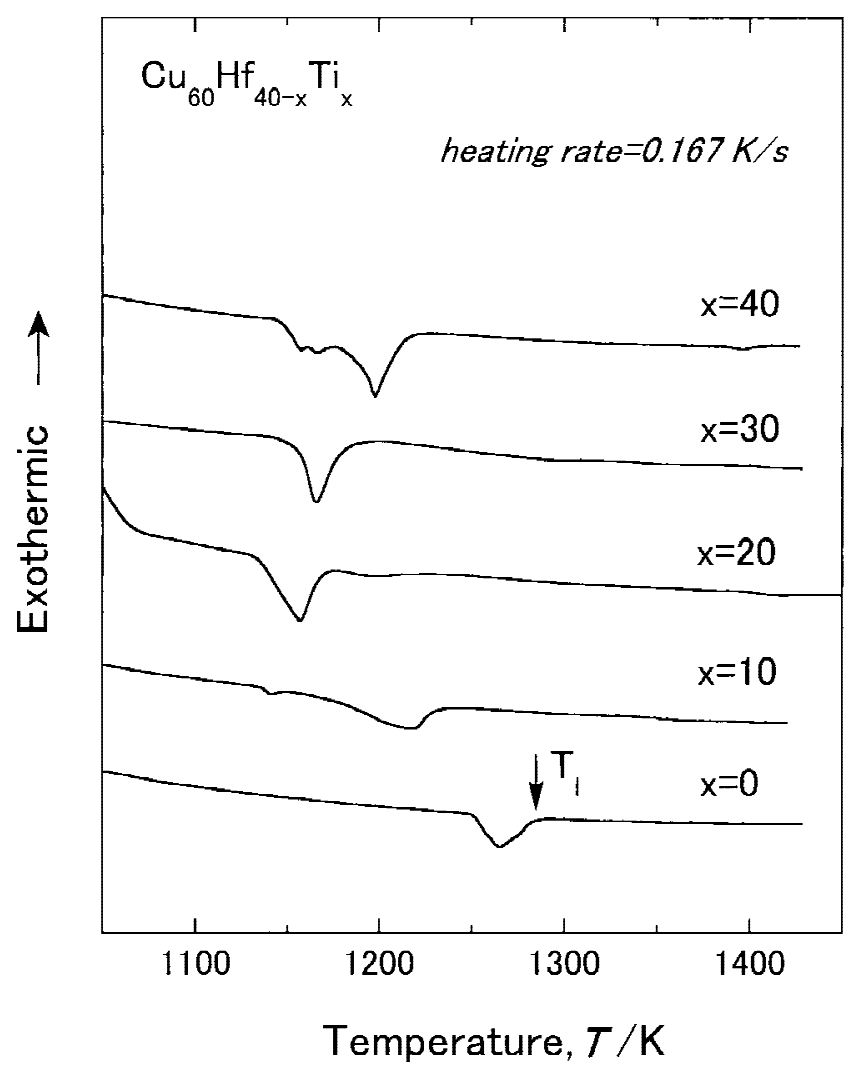

FIG. 4. DTA curves of the $\mathrm{Cu}_{60} \mathrm{Hf}_{40-x} \mathrm{Ti}_{x}(x=0$ to 40 at. $\%$ ) glassy alloys.

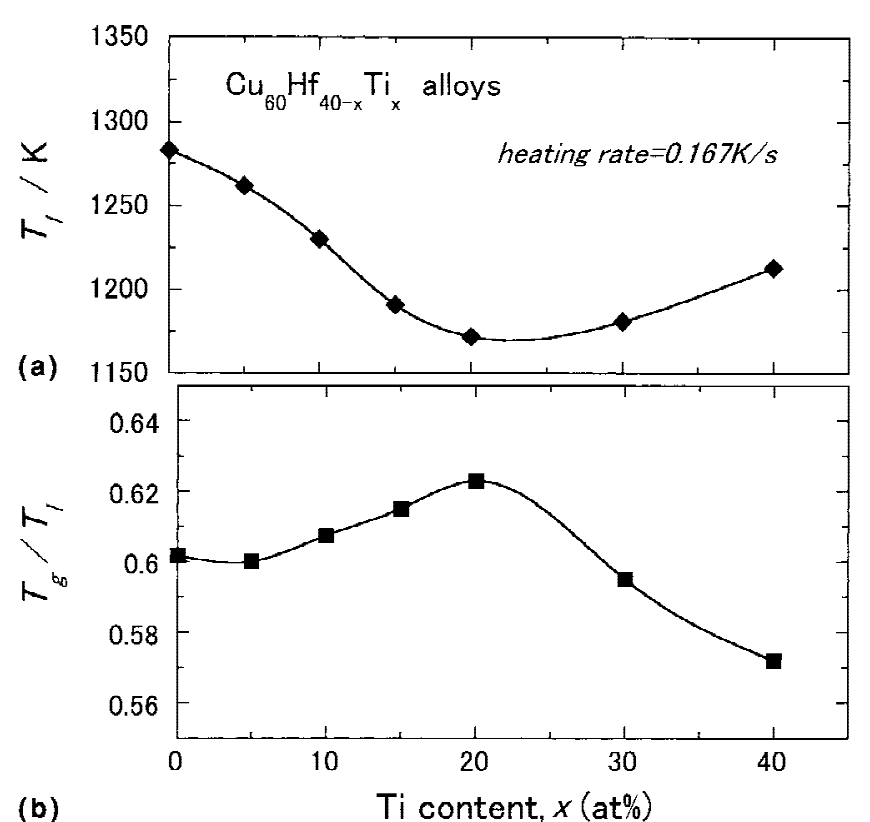

FIG. 5. Liquidus temperature $\left(T_{1}\right)$ and reduced glass transition temperature $\left(T_{\mathrm{g}} / T_{1}\right)$ as a function of $\mathrm{Ti}$ content for the $\mathrm{Cu}_{60} \mathrm{Hf}_{40-x} \mathrm{Ti}_{x}$ glassy alloys. 


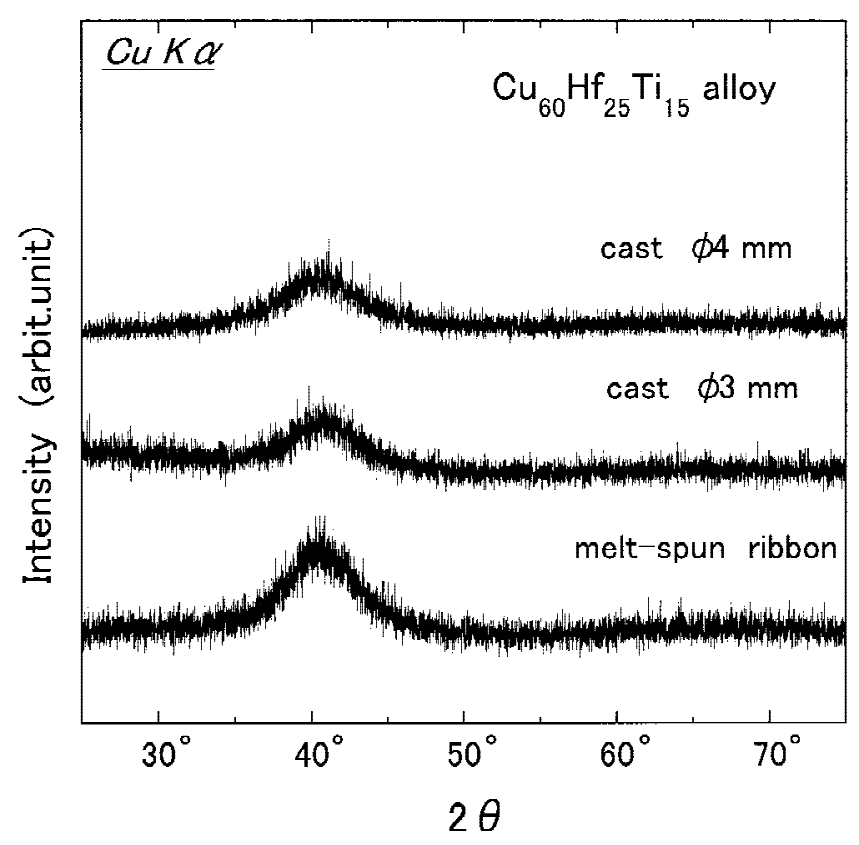

FIG. 6. XRD patterns of cast cylindrical $\mathrm{Cu}_{60} \mathrm{Hf}_{25} \mathrm{Ti}_{15}$ rods with diameters of 3 and $4 \mathrm{~mm}$. The data of the melt-spun ribbon are also shown for comparison.

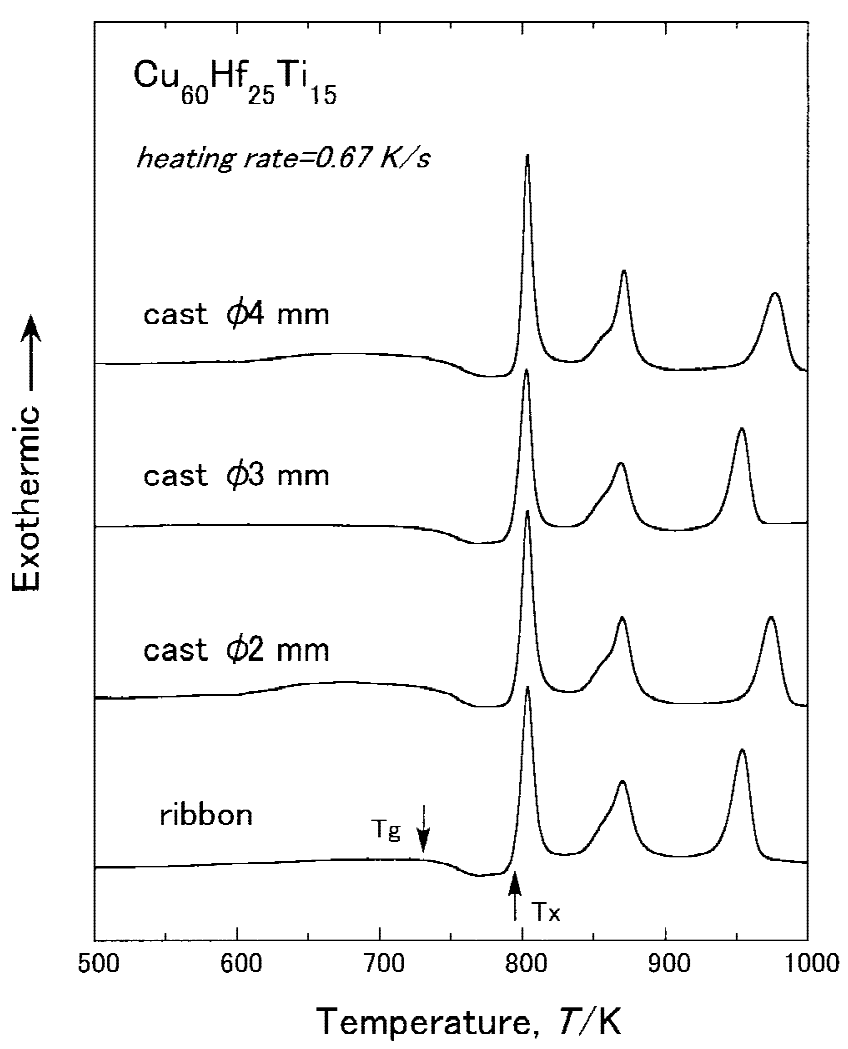

FIG. 7. DSC curves of cast $\mathrm{Cu}_{60} \mathrm{Hf}_{25} \mathrm{Ti}_{15}$ glassy rods with different diameters of 2 to $4 \mathrm{~mm}$. The data of the melt-spun ribbon are also shown for comparison.
It is expected that the decreases in $T_{\mathrm{g}}$ and $T_{\mathrm{x}}$ by the addition of Ti reflect the lowering in the liquidus temperature $\left(T_{1}\right)$ of the $\mathrm{Cu}_{60} \mathrm{Hf}_{40-x} \mathrm{Ti}_{x}$ alloys. Figure 4 shows DTA curves of the $\mathrm{Cu}_{60} \mathrm{Hf}_{40-x} \mathrm{Ti}_{x}(x=0$ to 40 at.\%) alloys. The endothermic peak due to melting is seen for all the alloys and the melting reaction appears to occur through a single stage for the $\mathrm{Cu}_{60} \mathrm{Hf}_{40}$, $\mathrm{Cu}_{60} \mathrm{Hf}_{20} \mathrm{Ti}_{20}$, and $\mathrm{Cu}_{60} \mathrm{Hf}_{10} \mathrm{Ti}_{30}$ alloys. On the basis of the data shown in Fig. 4, the $T_{1}$ and the reduced glass transition temperature $\left(T_{\mathrm{g}} / T_{1}\right)$ were plotted as a function of Ti content for the $\mathrm{Cu}_{60} \mathrm{Hf}_{40-x} \mathrm{Ti}_{x}$ alloys in Fig. 5. It is clearly seen that $\mathrm{T}_{1}$ shows a minimum of $1172 \mathrm{~K}$ at $20 \%$ Ti. As a result, the $20 \%$ Ti alloy exhibits a maximum $T_{\mathrm{g}} / T_{1}$ of 0.623 . Here, it is noticed that the high $T_{\mathrm{g}} / T_{1}$ values exceeding 0.61 are obtained for the $\mathrm{Cu}_{60} \mathrm{Hf}_{30} \mathrm{Ti}_{10}$, $\mathrm{Cu}_{60} \mathrm{Hf}_{25} \mathrm{Ti}_{15}$, and $\mathrm{Cu}_{60} \mathrm{Hf}_{20} \mathrm{Ti}_{20}$ glassy alloys. We have

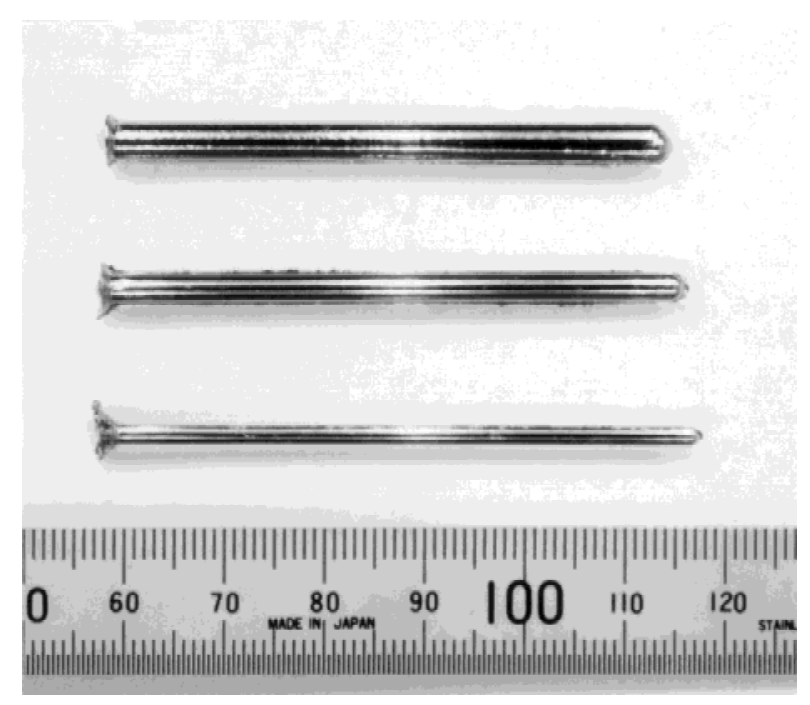

FIG. 8. Shape and outer surface appearance of cast $\mathrm{Cu}_{60} \mathrm{Hf}_{25} \mathrm{Ti}_{15}$ glassy rods with diameters of 2,3 , and $4 \mathrm{~mm}$.

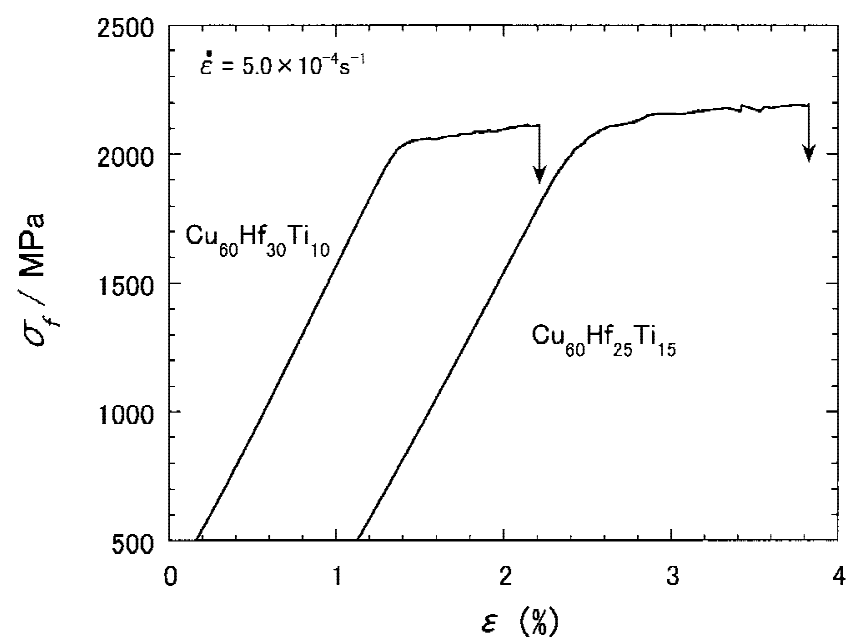

FIG. 9. Compressive stress-elongation curves of cast $\mathrm{Cu}_{60} \mathrm{Hf}_{30} \mathrm{Ti}_{10}$ and $\mathrm{Cu}_{60} \mathrm{Hf}_{25} \mathrm{Ti}_{15}$ glassy rods with a diameter of $2 \mathrm{~mm}$. 

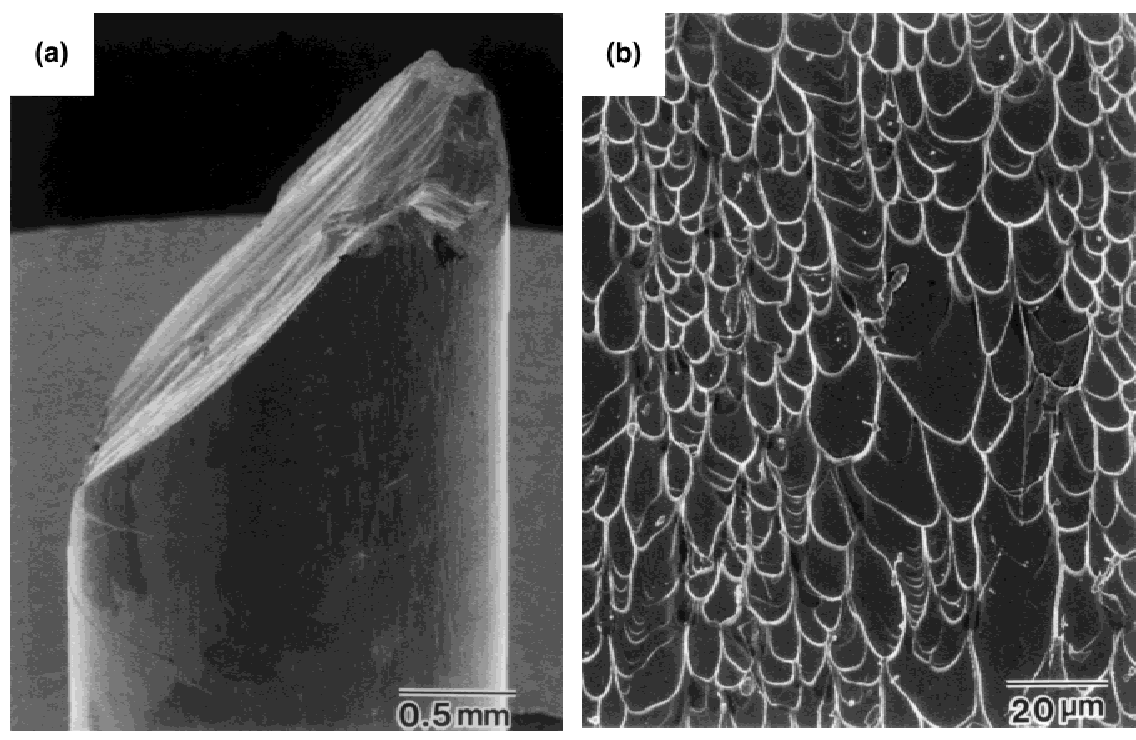

FIG. 10. Compressive fracture surface of the cast $\mathrm{Cu}_{60} \mathrm{Hf}_{25} \mathrm{Ti}_{15}$ glassy rod.

also confirmed that the $\mathrm{Cu}_{60} \mathrm{Zr}_{40-x} \mathrm{Ti}_{x}(x=0,10$, and 20 at.\%) glassy alloys show high $T_{\mathrm{g}} / T_{1}$ exceeding 0.60 and the highest $T_{\mathrm{g}} / T_{1}$ of 0.63 is obtained for the 20 at. $\%$ Ti alloy. Considering that a number of bulk glassy alloys are obtained for the alloys with high $T_{\mathrm{g}} / T_{1}$ above 0.60 by the copper mold casting method, ${ }^{22-24}$ it is expected that $\mathrm{Cu}$-based bulk glassy alloys are formed by choosing the alloy compositions $\mathrm{Cu}_{60} \mathrm{Hf}_{40-x} \mathrm{Ti}_{x}(x=10$ and $20 \%)$.

\section{B. Formation of bulk glassy alloys}

Figure 6 shows $\mathrm{x}$-ray diffraction patterns of the cylindrical $\mathrm{Cu}_{60} \mathrm{Hf}_{25} \mathrm{Ti}_{15}$ rods with diameters of 3 and $4 \mathrm{~mm}$. No distinct crystalline peaks are seen for the 3-and 4-mm samples, indicating the formation of a single glassy phase in the diameter range up to $4 \mathrm{~mm}$. Figure 7 shows DSC curves of the cast glassy alloy rods with diameters of 2,3 , and $4 \mathrm{~mm}$, together with the data of the melt-spun glassy alloy ribbon. The $T_{\mathrm{g}}, T_{\mathrm{x}}$, and heat of crystallization are nearly the same among the bulk and ribbon samples, being consistent with the results obtained from XRD. As an example, the outer surface appearance of the cast bulk glassy rods with diameters of 2, 3, and $4 \mathrm{~mm}$ is shown in Fig. 8. These rod samples exhibit good metallic luster, and no appreciable concavity due to a crystalline phase is recognized. We have also confirmed the absence of a crystalline phase in the optical micrographs taken from the central region of the transverse cross section of the 2-, 3-, and 4-mm rod samples. Here, it is important to point out that the further increase in the sample diameter causes the formation of crystalline phases, and hence, the critical diameter of the ternary $\mathrm{Cu}_{60} \mathrm{Hf}_{25} \mathrm{Ti}_{15}$ alloy lies between 4 and $5 \mathrm{~mm}$.

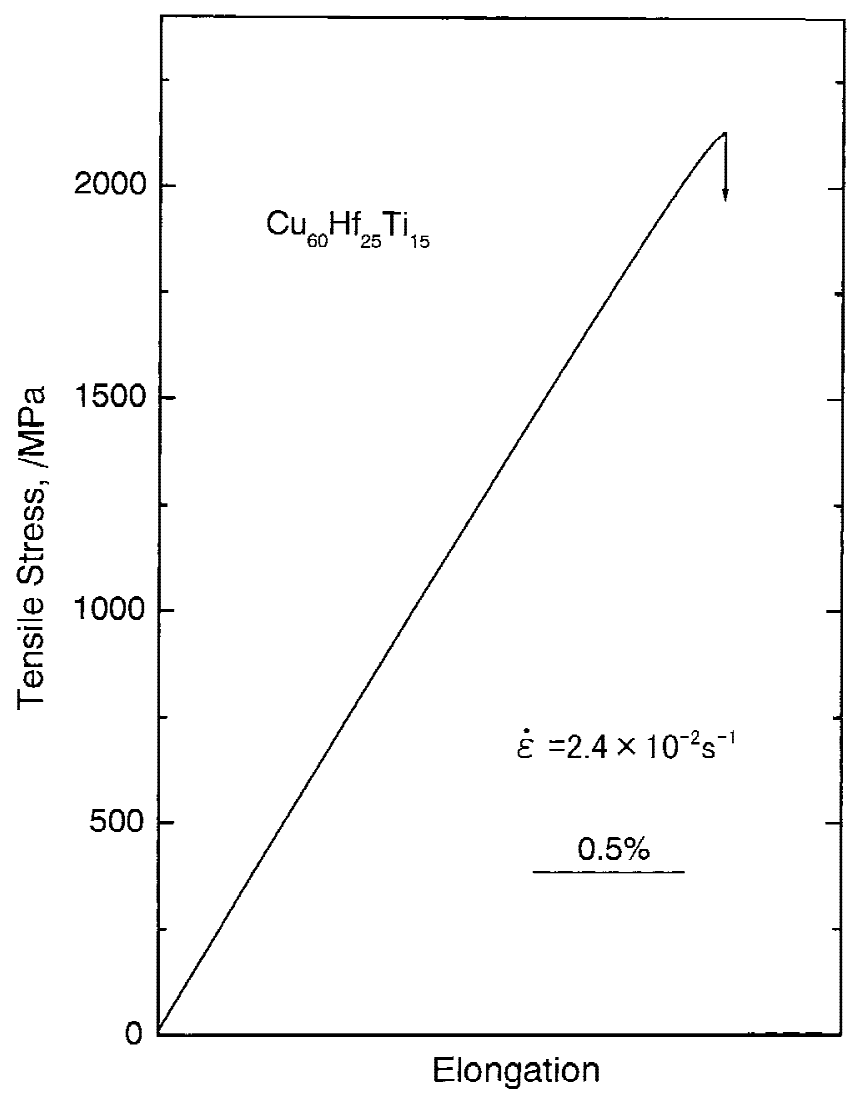

FIG. 11. Tensile stress-elongation curve of a cast $\mathrm{Cu}_{60} \mathrm{Hf}_{25} \mathrm{Ti}_{15}$ glassy sheet with a gauge dimension of $1 \mathrm{~mm}$ in thickness, $2 \mathrm{~mm}$ in width, and $10 \mathrm{~mm}$ in length. 

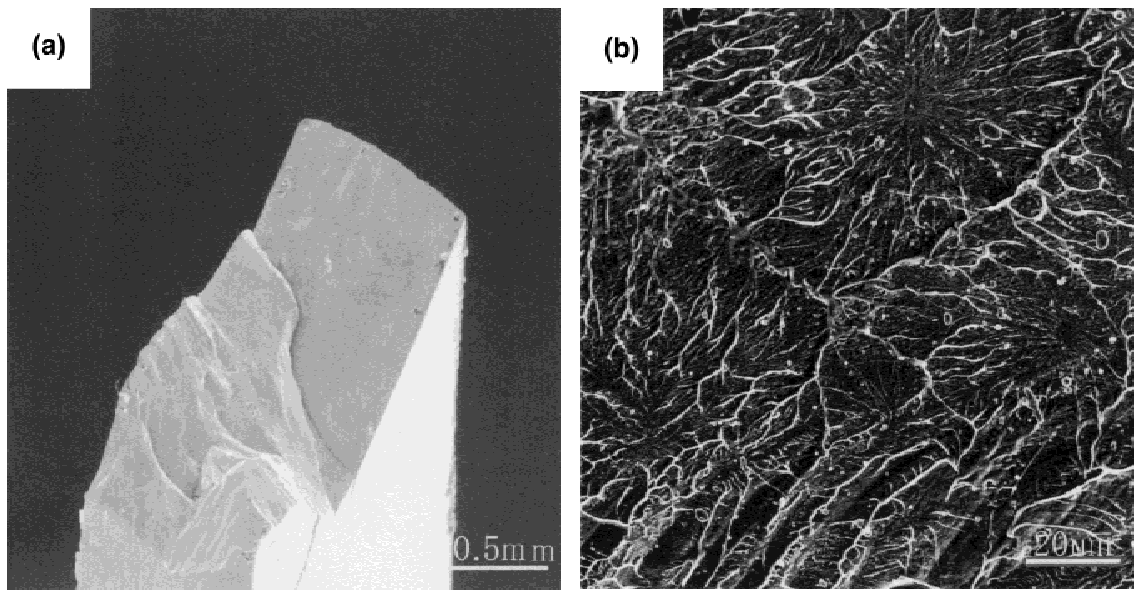

FIG. 12. Tensile fracture surface of the cast $\mathrm{Cu}_{60} \mathrm{Hf}_{25} \mathrm{Ti}_{15}$ glassy sheet.

\section{Mechanical properties of bulk glassy alloys}

Figure 9 shows compressive stress-strain curves of the cast bulk glassy $\mathrm{Cu}_{60} \mathrm{Hf}_{30} \mathrm{Ti}_{10}$ and $\mathrm{Cu}_{60} \mathrm{Hf}_{25} \mathrm{Ti}_{15}$ rods. It is seen that the glassy rods exhibit elastic elongation in the elongation range up to $1.8 \%$, followed by plastic elongation of about 0.8 to $1.6 \%$ and then final fracture, indicating that the new $\mathrm{Cu}$-based bulk glassy alloys have rather good ductility. Young's modulus $(E)$, compressive yield strength $\left(\sigma_{\mathrm{c}, \mathrm{y}}\right)$, and compressive fracture strength $\left(\sigma_{\mathrm{c}, \mathrm{f}}\right)$ are $119 \mathrm{GPa}, 1995 \mathrm{MPa}$, and $2120 \mathrm{MPa}$, respectively, for the $30 \% \mathrm{Hf}$ alloy and $124 \mathrm{GPa}, 2010 \mathrm{MPa}$, and $2160 \mathrm{MPa}$, respectively, for the $25 \% \mathrm{Hf}$ alloy. The fracture occurs along the maximum shear plane, which is declined by about $45^{\circ}$ to the direction of applied load, and the fracture surface consists of a well-developed vein pattern typical to Zr-based bulk glassy alloys with good ductility, ${ }^{22-24}$ as exemplified for $\mathrm{Cu}_{60} \mathrm{Hf}_{25} \mathrm{Ti}_{15}$ in Fig. 10. It is noticed that the fracture strength exceeds $2000 \mathrm{MPa}$ accompanying the distinct plastic elongations. The high fracture strength above $2000 \mathrm{MPa}$ was also obtained in the tensile deformation mode. Figure 11 shows a tensile stress-elongation curve of the bulk glassy $\mathrm{Cu}_{60} \mathrm{Hf}_{25} \mathrm{Ti}_{15}$ sheet. The $E$, tensile yield strength defined by the deviation point from the linear relation $\left(\sigma_{t, y}\right)$, tensile fracture strength $\left(\sigma_{\mathrm{t}, \mathrm{f}}\right)$, and fracture elongation including elastic elongation $\left(\epsilon_{\mathrm{f}}\right)$ are $120 \mathrm{GPa}, 1920 \mathrm{MPa}, 2130 \mathrm{MPa}$, and $1.9 \%$, respectively. The tensile fracture also occurs along the maximum shear plane and the developed vein pattern is seen over the whole fracture surface, as shown in Fig. 12. Furthermore, the Vickers hardness $\left(H_{\mathrm{v}}\right)$ was 670 for $\mathrm{Cu}_{60} \mathrm{Hf}_{25} \mathrm{Ti}_{15}$ and 640 for $\mathrm{Cu}_{60} \mathrm{Hf}_{20} \mathrm{Ti}_{20}$. Here, it is important to point out that the tensile fracture strength is nearly the same as the compressive fracture strength, indicating good ductility of the Cu-based bulk glassy alloy. There have been no data on high-strength $\mathrm{Cu}$-based bulk alloys with high strength above $2000 \mathrm{MPa}$ in crystalline and glassy states. ${ }^{22-24,29}$ However, it is known that the perfect crystal $\mathrm{Cu}$ whisker of $1 \mu \mathrm{m}$ in diameter exhibits high strength of $2000 \mathrm{MPa} .{ }^{30}$ It is noticed that the tensile strength of the present bulk glassy alloy is comparable to that for the $\mathrm{Cu}$ whisker in spite of the much larger dimension of the specimen. In addition, the high strength level exceeding $2000 \mathrm{MPa}$ has not been obtained for any $\mathrm{Zr}$-based bulk glassy alloys in $\mathrm{Zr}-\mathrm{Al}-\mathrm{Ni}-\mathrm{Cu},{ }^{30,31} \mathrm{Zr}-(\mathrm{Ti}, \mathrm{Nb}, \mathrm{Ta})-\mathrm{Al}-\mathrm{Ni}-\mathrm{Cu},{ }^{17,31-33}$ and $\mathrm{Zr}-\mathrm{Ti}-\mathrm{Be}-\mathrm{Ni}-\mathrm{Cu}^{6}$ systems. Consequently, the present $\mathrm{Cu}$-based bulk glassy alloys are expected to be developed as a new type of bulk structural material with higher strength combined with good ductility.

\section{DISCUSSION}

As described above, the maximum sample thickness, $\Delta T_{\mathrm{x}}$, and $T_{\mathrm{g}} / T_{1}$ are $4 \mathrm{~mm}, 60 \mathrm{~K}$, and 0.62 for the $\mathrm{Cu}_{60} \mathrm{Hf}_{25} \mathrm{Ti}_{15}$ glassy alloy and $4 \mathrm{~mm}, 38 \mathrm{~K}$, and 0.62 for the $\mathrm{Cu}_{60} \mathrm{Hf}_{20} \mathrm{Ti}_{20}$ glassy alloy. In addition, $\Delta T_{\mathrm{x}}$ and $T_{\mathrm{g}} / T_{1}$ of the $\mathrm{Cu}_{60} \mathrm{Hf}_{40}$ glassy alloy are $55 \mathrm{~K}$ and 0.60 , respectively, and the critical sample diameter is about $1 \mathrm{~mm}$. The relation among $\Delta T_{\mathrm{x}}, T_{\mathrm{g}} / T_{1}$, and maximum sample thickness for the ternary and binary glassy alloys indicates that the glass-forming ability defined by the maximum sample thickness is related to $\Delta T_{\mathrm{x}}$ and $T_{\mathrm{g}} / T_{1}$. That is, the higher glass-forming ability for the new $\mathrm{Cu}-$ based alloys was obtained at the compositions with larger $\Delta T_{\mathrm{x}}$ and higher $T_{\mathrm{g}} / T_{1}$ values. The increase in the $\Delta T_{\mathrm{x}}$ implies that the thermal stability of supercooled liquid against crystallization increases by the addition of Ti. In addition, the increase in $T_{\mathrm{g}} / T_{1}$ results from the lowering of $T_{1}$. It is therefore concluded that the formation of the bulk glassy alloys results from the increase in the resistance of supercooled liquid against crystallization. It is also noticed in Fig. 3 that the crystallization of the supercooled liquid occurs through a single exothermic reaction accompanying the simultaneous precipitation of at least three crystalline phases. The crystallization mode 

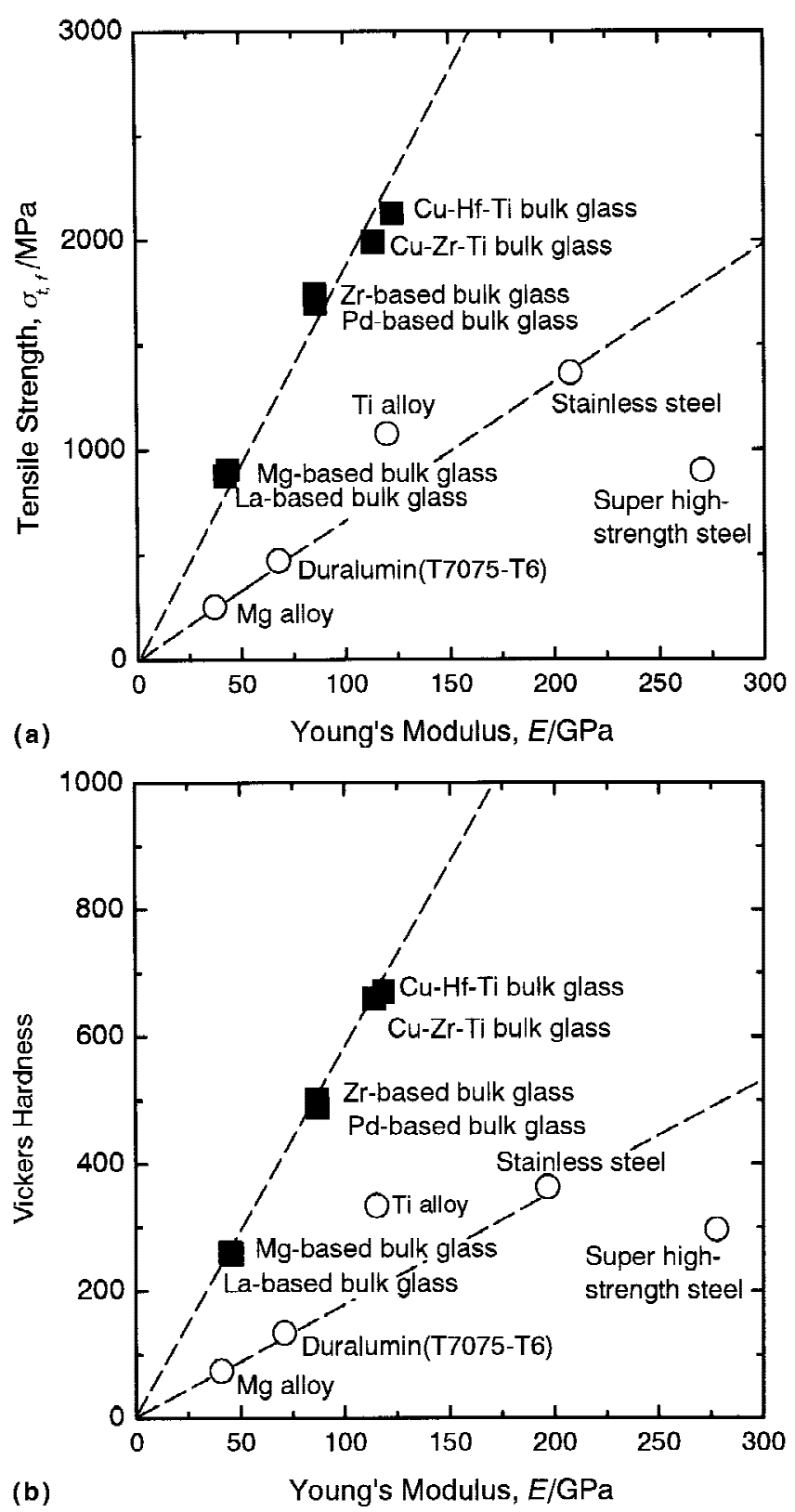

FIG. 13. Relationship between Young's modulus $(E)$ and tensile fracture strength $\left(\sigma_{\mathrm{t}, \mathrm{f}}\right)$ or Vickers hardness $\left(H_{\mathrm{v}}\right)$ for the cast $\mathrm{Cu}_{60} \mathrm{Hf}_{25} \mathrm{Ti}_{15}$ glassy sheet. The data of other bulk glassy alloys and conventional crystalline alloys are also shown for comparison.

implies the necessity of long-range rearrangements of the constituent elements for the progress of crystallization. The necessity suppresses the crystallization reactions, resulting in the formation of bulk glassy alloys.

Next, we discuss the reason for the slight deviation from the direct correlation among glass-forming ability, $\Delta T_{\mathrm{x}}$ and $T_{\mathrm{g}} / T_{1}$. It has previously been reported that the high glass-forming ability leading to the formation of a bulk glassy alloy is obtained in the multicomponent alloy systems with the following three empirical rules: ${ }^{22-24}$ (i) a multicomponent consisting of more than three
TABLE I. Glass transition temperature $\left(T_{\mathrm{g}}\right)$, crystallization temperature $\left(T_{\mathrm{x}}\right)$, supercooled liquid region $\left(\Delta T_{\mathrm{x}}=T_{\mathrm{x}}-T_{\mathrm{g}}\right)$, liquidus temperature $\left(T_{1}\right)$, and reduced glass transition temperature $\left(T_{\mathrm{g}} / T_{1}\right)$ for $\mathrm{Cu}-\mathrm{Hf}-\mathrm{Ti}$ bulk glassy alloys. The data of the $\mathrm{Cu}-\mathrm{Zr}-\mathrm{Ti}$ and $\mathrm{Zr}-\mathrm{Al}-$ $\mathrm{Ni}-\mathrm{Cu}$ bulk glassy alloys are also shown for comparison.

\begin{tabular}{lccccc}
\hline \hline $\begin{array}{c}\text { Composition } \\
\text { (at.\%) }\end{array}$ & $\begin{array}{c}T_{\mathrm{g}} \\
(\mathrm{K})\end{array}$ & $\begin{array}{c}T_{\mathrm{x}} \\
(\mathrm{K})\end{array}$ & $\begin{array}{c}\Delta T_{\mathrm{x}} \\
(\mathrm{K})\end{array}$ & $\begin{array}{c}T_{1} \\
(\mathrm{~K})\end{array}$ & $T_{\mathrm{g}} / T_{1}$ \\
\hline $\mathrm{Zr}_{55} \mathrm{Al}_{10} \mathrm{Ni}_{5} \mathrm{Cu}_{30}$ & 690 & 755 & 85 & 1113 & 0.62 \\
$\mathrm{Zr}_{60} \mathrm{Al}_{10} \mathrm{Ni}_{10} \mathrm{Cu}_{20}$ & 676 & 770 & 94 & 1095 & 0.62 \\
$\mathrm{Cu}_{60} \mathrm{Zr}_{30} \mathrm{Ti}_{10}$ & 713 & 750 & 37 & 1153 & 0.62 \\
$\mathrm{Cu}_{60} \mathrm{Zr}_{20} \mathrm{Ti}_{20}$ & 708 & 768 & 38 & 1127 & 0.63 \\
$\mathrm{Cu}_{60} \mathrm{Hf}_{25} \mathrm{Ti}_{15}$ & 732 & 792 & 60 & 1191 & 0.62 \\
$\mathrm{Cu}_{60} \mathrm{Hf}_{20} \mathrm{Ti}_{20}$ & 730 & 768 & 38 & 1172 & 0.62 \\
\hline \hline
\end{tabular}

elements; (ii) significant atomic size mismatches above $12 \%$; (iii) suitable negative heats of mixing. In the $\mathrm{Cu}-$ Hf-Ti system, their atomic sizes change in the order of $\mathrm{Hf}>\mathrm{Ti}>\mathrm{Cu}$ and the atomic size ratios are 1.08 for $\mathrm{Hf} / \mathrm{Ti}$ and 1.14 for $\mathrm{Ti} / \mathrm{Cu}^{34}$ In addition, the heats of mixing have been estimated to be $-9 \mathrm{~kJ} / \mathrm{mol}$ for $\mathrm{Cu}-\mathrm{Ti}$, $-17 \mathrm{~kJ} / \mathrm{mol}$ for $\mathrm{Cu}-\mathrm{Hf}$, and $0 \mathrm{~kJ} / \mathrm{mol}$ for $\mathrm{Hf}-\mathrm{Ti}^{35}$ These data on the atomic size ratios and heats of mixing imply that the present $\mathrm{Cu}$-based alloys do not perfectly satisfy the three empirical rules. The insufficient condition is thought to result in a disagreement of alloy compositions where the largest $\Delta T_{\mathrm{x}}$ and the highest $T_{\mathrm{g}} / T_{1}$ are obtained. That is, the largest $\Delta T_{\mathrm{x}}$ and the largest maximum sample thickness are obtained at 5\% $\mathrm{Ti}$ and 10 to $15 \% \mathrm{Ti}$, respectively, while the highest $T_{\mathrm{g}} / T_{1}$ is obtained at $20 \% \mathrm{Ti}$ owing to the significant lowering of $\mathrm{Ti}$ at $20 \% \mathrm{Ti}$. The search for an appropriate element leading to agreement of the alloy compositions among the largest $\Delta T_{\mathrm{x}}$, the highest $T_{\mathrm{g}} / T_{1}$, the lowest $T_{1}$, and maximum sample diameter is also expected to cause the formation of a bulk glassy alloy with a larger diameter.

It was shown in Fig. 11 that the $\mathrm{Cu}-\mathrm{Hf}-\mathrm{Ti}$ bulk glassy alloy exhibits high tensile fracture strength of $2130 \mathrm{MPa}$ which is comparable to that (1700 to $2900 \mathrm{MPa}$ ) for a $\mathrm{Cu}$ whisker with perfect crystal structure ${ }^{30}$ and much higher than that (1600 to $1700 \mathrm{MPa}$ ) for Zr-based bulk glassy alloys in $\mathrm{Zr}-\mathrm{Al}-\mathrm{Ni}-\mathrm{Cu},{ }^{31} \mathrm{Zr}-(\mathrm{Ti}, \mathrm{Nb})-\mathrm{Al}-\mathrm{Ni}-$ $\mathrm{Cu},{ }^{17,31-33}$ and $\mathrm{Zr}-\mathrm{Ti}-\mathrm{Be}-\mathrm{Ni}-\mathrm{Cu}^{6}$ systems. Here, we discuss the reason for the extremely high tensile fracture strength for the $\mathrm{Cu}$-based bulk glassy alloy. Figure 13 summarizes the relationship between $E$ and $\sigma_{\mathrm{t}, \mathrm{f}}$ or $H_{\mathrm{v}}$ for the $\mathrm{Cu}_{60} \mathrm{Hf}_{25} \mathrm{Ti}_{15}$ bulk glassy alloy, together with the data of other bulk glassy alloys including the $\mathrm{Cu}_{60} \mathrm{Zr}_{30} \mathrm{Ti}_{10}$ bulk glassy alloy. ${ }^{21}$ There is a clear tendency for $E$ to increase with an increase of $\sigma_{\mathrm{t}, \mathrm{f}}$ or $H_{\mathrm{v}}$ for all the bulk glassy alloys. The slope in the linear relation for the bulk glassy alloys is also significantly different from that for the conventional crystalline alloys. It is characterized that the bulk glassy alloys have lower Young's modulus, larger elastic elongation limit, and higher strength as compared with those for the conventional crystalline 

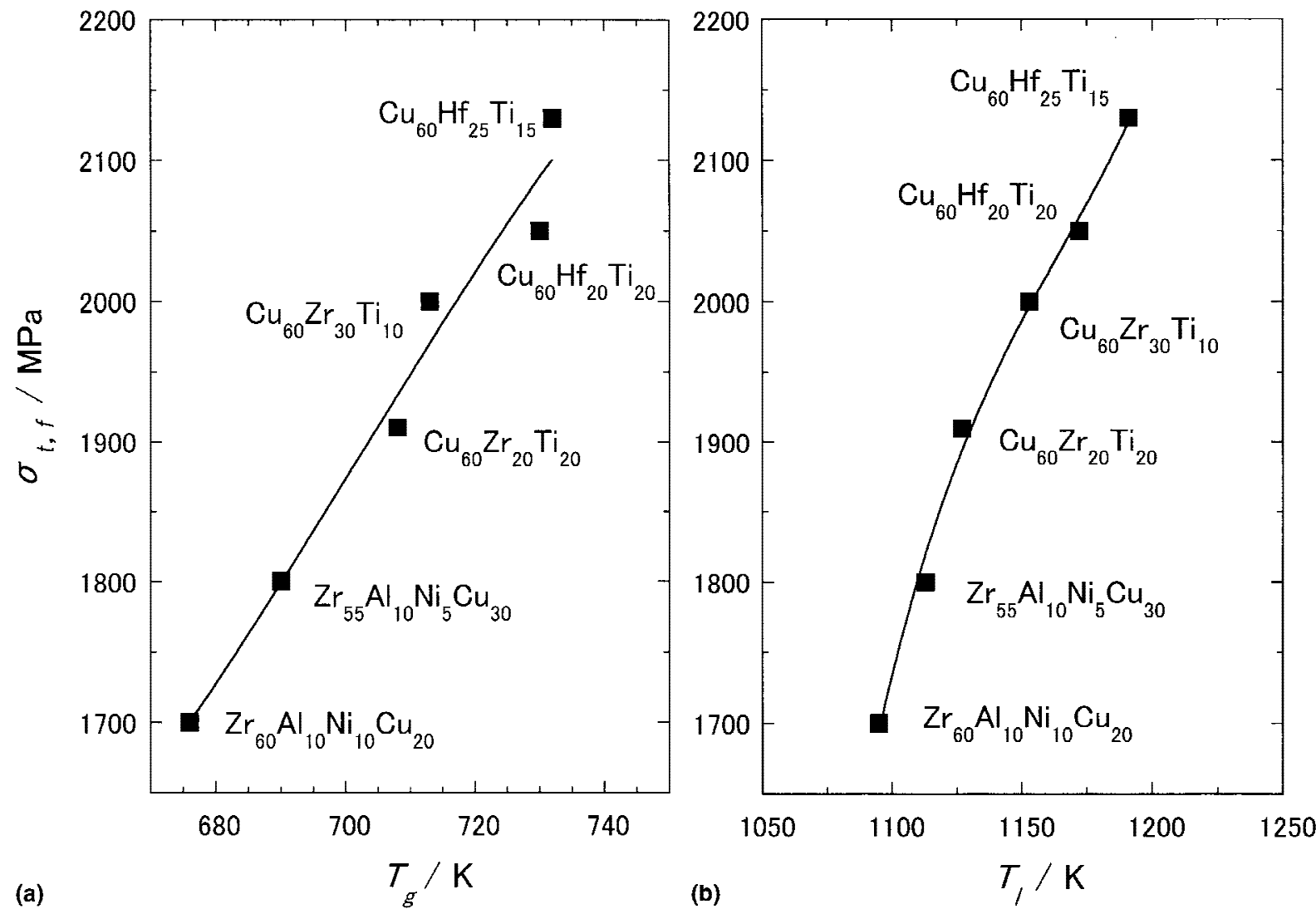

FIG. 14. Relationship between tensile fracture strength $\left(\sigma_{\mathrm{t}, \mathrm{f}}\right)$ and glass transition temperature $\left(T_{\mathrm{g}}\right)$ or liquidus temperature $\left(T_{1}\right)$ for the cast $\mathrm{Cu}-\mathrm{Hf}-\mathrm{Ti}$ glassy sheets. The data of the cast $\mathrm{Cu}-\mathrm{Zr}-\mathrm{Ti}$ and $\mathrm{Zr}-\mathrm{Al}-\mathrm{Ni}-\mathrm{Cu}$ glassy alloys are also shown for comparison.

alloys. It has been pointed out that the $T_{\mathrm{g}}$ and $T_{1}$ of glassy alloys reflect the degree of bonding force among the constituent elements. ${ }^{36}$ As shown in Table I, the $T_{\mathrm{g}}$ and $T_{1}$ of the $\mathrm{Cu}-\mathrm{Hf}-\mathrm{Ti}$ ternary glassy alloys are higher than those for the $\mathrm{Zr}-\mathrm{Al}-\mathrm{Ni}-\mathrm{Cu}$ and $\mathrm{Cu}-\mathrm{Zr}-\mathrm{Ti}$ glassy alloys. The higher values of $T_{\mathrm{g}}$ and $T_{1}$ allow us to presume that the bonding force among the $\mathrm{Cu}$, Hf, and $\mathrm{Ti}$ elements is stronger than that among the $\mathrm{Zr}, \mathrm{Al}, \mathrm{Ni}$, and $\mathrm{Cu}$ elements as well as among the $\mathrm{Cu}, \mathrm{Zr}$, and Ti elements. In addition, the relations between $\sigma_{\mathrm{t}, \mathrm{f}}$ and $T_{\mathrm{g}}$ or $T_{1}$ for the $\mathrm{Cu}-\mathrm{Hf}-\mathrm{Ti}, \mathrm{Cu}-\mathrm{Zr}-\mathrm{Ti}$, and $\mathrm{Zr}-\mathrm{Al}-\mathrm{Ni}-\mathrm{Cu}$ bulk glassy alloys are shown in Fig. 14. Although some scatterings are seen, one can recognize a strong correlation, demonstrating an appropriateness of the previous concept between strength and $T_{\mathrm{g}}$ or $T_{1}$.

\section{SUMMARY}

We have searched for a new Cu-based bulk glassy alloy with good mechanical properties which can be produced by the copper mold casting methods. The results obtained are summarized as follows.

(1) In the $\mathrm{Cu}_{60} \mathrm{Hf}_{40-x} \mathrm{Ti}_{x}$ alloy system, $T_{\mathrm{g}}$ decreases monotonously with increasing $\mathrm{Ti}$ content, while $T_{\mathrm{x}}$ shows a maximum at 5 at. $\% \mathrm{Ti}$ and $T_{1}$ shows a minimum at 20 at.\% Ti. The resulting $\Delta T_{\mathrm{x}}$ shows a maximum of $78 \mathrm{~K}$ at 5 at. $\% \mathrm{Ti}$, followed by a gradual decrease to $60 \mathrm{~K}$ at $15 \% \mathrm{Ti}$ and then a significant decrease to $28 \mathrm{~K}$ at $30 \%$ Ti. No glass transition is observed for $\mathrm{Cu}_{60} \mathrm{Ti}_{40}$.

(2) The $T_{\mathrm{g}} / T_{1}$ shows a maximum value of 0.62 at 20 at.\% Ti because of the minimum value of $1172 \mathrm{~K}$ for $\mathrm{T}_{1}$ at $20 \% \mathrm{Ti}$.

(3) The bulk glassy alloys were formed in the ternary system, and the largest diameter is $4 \mathrm{~mm}$ for the $\mathrm{Cu}_{60} \mathrm{Hf}_{25} \mathrm{Ti}_{15}$ alloy. The bulk glass-forming ability is more closely related to $T_{\mathrm{g}} / T_{1}$ rather than $\Delta T_{\mathrm{x}}$.

(4) The bulk glassy alloys possess good mechanical properties, i.e., Young's modulus of 119 to $124 \mathrm{GPa}$, yield strength of 1995 to $2010 \mathrm{MPa}$, compressive fracture strength of 2120 to $2160 \mathrm{MPa}$, tensile fracture strength of $2130 \mathrm{MPa}$, elastic elongation of 1.6-2.0\%, and compressive plastic elongation of 0.8 to $1.6 \%$. The good combination of high glass-forming ability and good mechanical properties for the $\mathrm{Cu}$-based alloys indicates the possibility of future development as a new type of bulk structural material.

\section{REFERENCES}

1. A. Inoue, T. Zhang, and T. Masumoto, Mater. Trans. JIM 30, 965 (1989). 
2. A. Inoue, K. Ohtera, K. Kita, and T. Masumoto, Jpn. J. Appl. Phys. 27, L2248 (1988).

3. A. Inoue, T. Zhang, and T. Masumoto, Mater. Trans. JIM 31, 425 (1990).

4. A. Inoue, A. Kato, T. Zhang, S.G. Kim, and T. Masumoto, Mater. Trans. JIM 32, 609 (1991).

5. A. Inoue, T. Zhang, and T. Masumoto, Mater. Trans. JIM 31, 177 (1990).

6. A. Peker and W.L. Johnson, Appl. Phys. Lett. 63, 2342 (1993).

7. A. Inoue, T. Zhang, N. Nishiyama, K. Ohba, and T. Masumoto, Mater. Lett. 19, 131 (1994).

8. A. Inoue and G.S. Gook, Mater. Trans. JIM 36, 1180 (1995).

9. A. Inoue, N. Nishiyama, and T. Matsuda, Mater. Trans. JIM 37, 181 (1996).

10. X.M. Wang and A. Inoue, Mater. Trans. JIM 41, 542 (2000).

11. T. Itoi and A. Inoue, Mater. Trans. JIM 38, 359 (1997).

12. A. Inoue, K. Ohtera, A.P. Tsai, and T. Masumoto, Jpn. J. Appl. Phys. 27, L280 (1988).

13. Y. He, S.J. Poon, and G.J. Shiflet, Science 23, 1640 (1988).

14. A. Inoue, M. Oguchi, K. Matsuzaki, and T. Masumoto, Int. J. Rapid Solidif. 1, 273 (1984-5).

15. A. Inoue, N. Matsumoto, and T. Masumoto, Mater. Trans. JIM 31, 493 (1990).

16. A. Inoue, N. Yana, and T. Masumoto, J. Mater. Sci. 19, 3786 (1984).

17. A. Inoue, T. Shibata, and T. Zhang, Mater. Trans. JIM 36, 1420 (1995).

18. X.H. Lin and W.L. Johnson, J. Appl. Phys. 78, 6514 (1995).

19. T. Zhang and A. Inoue, Mater. Trans. JIM 40, 301 (1999).
20. C. Li, J. Saida, M. Kiminami, and A. Inoue, J. Non-Cryst. Solids 261, 108 (2000).

21. A. Inoue, W. Zhang, T. Zhang, and K. Kurosaka, Mater. Trans. 42, 1149 (2001).

22. A. Inoue, Mater. Trans. JIM 36, 866 (1995).

23. A. Inoue, Mater. Sci. Eng. A 226-228, 357 (1997).

24. A. Inoue, Acta Mater. 48, 279 (2000).

25. Metals Databook, edited by Japan Institute of Metals (Maruzen, Tokyo, Japan, 1983), p. 12.

26. A. Inoue and E. Makabe, Japanese Patent, 3011904 (1997).

27. H. Kakiuchi, A. Inoue, M. Onuki, Y. Takano, and T. Yamaguchi, Mater. Trans. JIM 42, 678 (2001).

28. A. Inoue, C. Suryanarayana, and T. Masumoto, J. Mater. Sci. 16, 1391 (1981).

29. Metals Handbook, edited by Japan Institute of Metals (Maruzen, Tokyo, Japan, 2000), p. 365.

30. Metals Handbook, edited by Japan Institute of Metals (Maruzen, Tokyo, 2000), p. 331.

31. T. Zhang and A. Inoue, Mater. Trans. JIM 39, 1230 (1998).

32. T. Zhang and A. Inoue, Mater. Trans. JIM 39, 859 (1998).

33. R.D. Conner, H. Choi Kim, and W.L. Johnson, J. Mater. Res. 14, 3292 (1999).

34. Metals Databook, edited by Japan Institute of Metals (Maruzen, Tokyo, Japan, 1983), p. 8.

35. F.R. de Boer, R. Boom, W.C.M. Mattens, A.R. Miedema, and A.K. Niessen, Cohesion in Metals (North-Holland, Amsterdam, The Netherlands, 1988).

36. H.S. Chen, Rep. Prog. Phys. 43, 353 (1980). 